\title{
FREE YOUR MIND: CONTEMPORARY RACIAL ATTITUDES AND POST RACIAL THEORY
}

\author{
Lakeyta M. Bonnette \\ Georgia State University
}

Sarah M. Gershon

Georgia State University

\author{
Precious D. Hall \\ Truckee Meadows Community College
}

In November 2008, the United States elected its first African American president. Preceding the election, pundits, academics, and the candidates themselves, debated whether Barack Obama (or any African American for that matter) could potentially become the first Black president of the United States. Central to these arguments was the role of race in politics and society at large. If race remained a significant cleavage in American society (many argued), it seemed unlikely that any member of a racial minority group would be able to win in a majority white America. In the days and weeks following the 2008 presidential election, it was frequently suggested that Obama's success was some indicator that Martin Luther King Jr's "dream" of a society that did not use race as its dominant predictor of character was actualized (see Thernstrom 2008).

Since Obama's election, both scholars and political pundits have engaged in arguments over whether America has in fact moved toward a point where race is no longer the defining cleavage in American society (e.g.; Piston 2010; Steele 2008; Teasley and Ikard 2010; Thernstrom 2008). On the one hand, events such as the election of President Obama as well as that of Michael Steele as chair of the Republican National Committee may very well indicate that Americans place less emphasis on race when voting for their political leaders. However, there still remains evidence to suggest that we are not in a new phase of post-racial politics and a post-racial America. During Obama's first campaign there was an emphasis on his race to designate distinction, deviancy, and fear. For example, the image of Michelle and Barack Obama on the cover of the New Yorker displayed, among other things, racism and xenophobia. In this image not only was the fist-bump displayed, (that previously had been denoted as "terrorist" by the McCain-Palin camp), but also a depic- 
tion of Michelle Obama donning an afro, an assault rifle and military fatigues while presidential candidate Barack Obama was wearing Islamic attire alluding to his suggested Islamic connections. Also, depicted in the background of this image was a picture of Osama Bin Laden and the burning of the American flag in the fireplace. This insidious image was in fact inherently racist and xenophobic. But images and racist depictions of the Obama's were not the only indication that racism is still prevalent. After Obama's election there were a number of racist incidents. In Snellville, Ga an elementary school boy was told by his classmate that he ". . hopes Obama gets assassinated" (www.nbcnews.com) ${ }^{1}$. In the same town, someone trashed a woman's lawn that featured Obama election signs and placed feces in a pizza box on her front door. Similarly, crosses were burned on people's front yards who were Obama supporters, threatening letters were left on the cars of Obama supporters and images of Obama were defaced and threatening messages were visible (www.nbcnews.com). ${ }^{2}$ Given the confluence of these racially polarizing events, we cannot conclude that we are living in a post-racial or "color blind" society as some suggest.

One indicator that Americans are moving in the direction of postracialism are the attitudes they adopt. That is to say, the less Americans believe race defines differences among their fellow citizens (in politics, attitudes and behavior) the closer we may become to a society in which race is no longer a defining cleavage. Shifting attitudes on race may have serious political, and policy-making implications. For instance, if Americans no longer believe race matters, they may be less inclined to recognize continuing discrimination or persistent racial inequalities. As a result, support for policies aimed at curbing discrimination and ensuring racial equality may weaken. More positively, a shift towards post-racial attitudes (particularly among white Americans) may improve the prospects of minority candidates seeking public office, thus increasing minority representation. Clearly, the potential implications of a shift towards more post-racial thinking among Americans are significant. As such, identifying and understanding these attitudes is critical.

In this article, we examine the prevalence and predictors of so called "post-racial" attitudes, relying on data collected in 2007 by the Pew Research Center. In our examination, we find significant variation in the presence of post-racial attitudes among respondents based on their race and experiences. Specifically, we find that whites and those respondents with diverse social groups are the most likely to express post-racial attitudes, controlling for other explanations. We conclude with a discussion of the implications of our findings. 


\section{Racial Differences in Public Opinion: Previous Literature AND THEORY}

The majority of research on racial attitudes in America has examined attitudes related to race and discrimination as well as explicitly and implicitly racial issues/policies among blacks and whites, with the bulk of this research finding significant differences among black and white Americans in this regard (e.g.; Hutchings and Valentino 2004; Kinder and Sanders 1996). The existing research may be thought of as falling into three major theoretical camps: "sociopsychological" theories, "social structural" theories and "political" theories of racial attitudes (Harris-Lacewell, 2003).

Included in the "sociopsychological" approach are studies of subtle or ambivalent racism, aversive racism, covert racism, and the more popular approaches of racial resentment or symbolic/modern racism (Devine 1989; Gaertner and Dovidio 1986; Kinder and Sears 1981; Pettigrew and Meertens 1995; Sears, Hetts, Sidanius and Bobo 2000). Symbolic racism, often argued by Kinder and Sears (1981), contends that "anti-Black affect and traditional American values contributes to White resistance toward affirmative action and other government sponsored remedies for racial inequality" (Harris-Lacewell 2003, 225-226). This theoretical camp is often confirmed by observing opinion over time, which demonstrates that overt 'biological' racial attitudes, such as beliefs that Blacks are inferior, are no longer supported. Instead, this research typically finds that contemporary whites' negative stereotypes of blacks' values and behaviors, combined with their support for core American values of work ethic and self-reliance, leads to a more subtle form of 'symbolic' or 'new' racism based largely on the perception that blacks violate traditional American values (Sears, Hettts, Sidanius and Bobo 2000).

Symbolic or 'new' racism is typically measured relying on several questions tapping attitudes about the prevalence of discrimination, attitudes about the work ethic of blacks and whether they have received undue advantages or government assistance (Kinder and Mendelberg 2000; Kinder and Sanders 1996; Sears, Henry and Kosterman 2000; Tarman and Sears 2005). The symbolic racism literature has also clearly demonstrated the impact of these orientations on whites' support for policies which are both explicitly and implicitly related to race (e.g.; welfare and affirmative action), decreasing support for such policies (Kinder and Mendelberg 2000; Tarman and Sears 2005).

The second theoretical approach to studying racial attitudes is the "social structural" approach. This set of theories consists of social dominance theory, group threat, racial threat theory, realistic group conflict theory, social identity theory and implicit stereotyping (Devine 1989; Dovidio et al. 1997; Fazio et al. 1995; Sidanius and Pratto 1999; Tajfel 
and Turner 1986). This approach asserts that individuals identify with groups that share their racial and/or ethnic identity. Whites' opposition to racial policies is then believed to be largely due to perceptions of conflict with other racial and ethnic groups, namely blacks (Sears, Hetts, Sidanius, and Bobo 2000). Sidanius and Pratto (1999) suggest that "group based social hierarchies are reproduced by interaction and reinforcement of inequality by individuals or institutions of the dominant group" (Harris-Lacewell 2003, 226).

Proponents of the social structural approach often situate racial attitudes derived from group interests in historical context, theorizing, for example, that while white racial attitudes might have evolved from the earlier form of 'biological' racism toward a newer form of 'laissez-faire' racism, the desire among whites to maintain a dominant position in society remains the same (Bobo, Kluegel and Smith 1997). As with the symbolic racism literature, scholars examining group threat have found whites' racial attitudes to be strongly linked with their support (or lack thereof) for policies linked to race (Bobo 2000).

The final approach to understanding racial attitudes is the political (sometimes called the "politics-centered") approach which suggests that "disagreements over racial policies are of ten about political rather than racial attitudes" (Harris-Lacewell 2003, 226). Proponents of this approach assert that political orientations (particularly about the role of government) and not racial attitudes, shape whites' support for racial policies (Sniderman and Piazza 1993; Sinderman and Carmines 1997). These scholars do not deny the existence of racial attitudes, however, their research suggests that the role of these attitudes in determining policy preferences is minimal. In other words, it is the policy and not prejudices or racial resentment that causes political disagreements. To support their claims regarding the current role of race in white opposition to various policies, these scholars have found weak relationships between racial attitudes and policy preferences, finding political orientations and values much more powerful predictors of such policy support (e.g.; Sniderman, Crosby and Howell 2000).

Observing all of these theories, we can conclude that understanding racial attitudes is important in political society. Racial attitudes do not only manifest in policy decisions but also election and participation decisions for both African Americans and Caucasian Americans. The study of racial attitudes in American politics continues to play a major role during this era in which an African American has secured the political position of the presidency and at a time in which there are contentious campaign rallies. Furthermore, the variation described in the racial attitudes literature demonstrates how difficult it is to conclude on the "best" measures of racism in American politics. Thus, we focus not on racism 
but on the idea of an elimination of racial categorization as a defining factor in political and policy assessment. If what the pundits argue is true, that we are moving towards a post racial society, we should observe a decline in the support of typical racism predictors among all groups.

\section{Post-Racialism}

While numerous scholars have written about the possibility of a post-racial society or the presence of post-racial candidates, attitudes, etc., few have offered a clear definition and measurement schema of post-racialism. Conventional research suggests that a post-racial society is one in which defining cleavages do not fall along racial lines (Cho 2009; Edge 2010; Gallagher 2003; Hutchings 2009; Steele 2008). For instance, Cho argues that post-racialism is an ideology that asserts, because of "significant racial progress that has been made, the state need not engage in race-based decision making or adopt race-based remedies, and that civil society should eschew race as a central organizing principle. . ." (Cho, 2009,1589). She also states that there are four central features to post-racialism, "racial progress, race neutral universalism, moral equivalence and distancing move" (Cho, 2009 1600). Other scholars' discussion of post-racialism mirror many of Cho's assertions, discussing post-racialism as the belief that race is no longer a significant impediment for blacks seeking employment, higher education, or political office (Metzler 2010). Metzler (2010) asserts, for example, that a white person who has adopted post-racial attitudes is someone who,
... situates racism in the past; embraces formal equality; believes that America has done so much for Blacks and yet Blacks never seem to think that it is enough; walks on eggshells around Blacks for fear of saying something offensive; believes in interracial dating so long as it is not their son or daughter who is marrying Black; does not see themselves as racialized but basks in White priv- ilege; believes that Blacks use race as an excuse for fail- ure, that Blacks who are successful are the exception; believes that pretending that race does not matter makes it true; and still harbors and makes decisions based on the powerful marker of race that is imbedded in Ameri- can racial reality. (Metzler 2010, 402)

Thus, post-racialism requires a belief that racial equality essentially exists and that race will have little impact on black American's prospects.

While, we have observed many articulations of what post-racialism looks like and how it is articulated, the quantitative evidence on postracialism is minimal. Vincent Hutchings (2009), one of the few scholars 
who have attempted to empirically measure post-racism, primarily by comparing support for racial policies from ANES data collected in 1988 to ANES data collected twenty years later in 2008, finds little evidence of a decline in a racial divide among Americans. He concludes that the post-racial society that many allude to is not evident when observing Black and White Americans' views on policy issues such as affirmative action, governmental aid and fair job treatment (Hutchings 2009).

To add to this limited research on post-racialism, we explore the presence and predictors of post-racial attitudes, focusing primarily on the extent to which Americans (blacks and whites) believe race to be a significant challenge for African Americans (seeking political office, housing, employment, education, etc), and the extent to which they believe differences among whites and blacks have become smaller in recent years.

\section{Data, Methods, and Measures}

To examine the presence and consequences of post-racial attitudes among Americans, we rely on survey data from the Pew Center's 2007 "Racial Attitudes in America" Survey. We rely on this survey not only due to the number of measures tapping attitudes towards race and politics, but due to its oversample of racial and ethnic minorities. The initial sample consisted of 1,500 non-Hispanic whites, 1,000 non-Hispanic blacks and 500 Hispanics. ${ }^{3}$ Since this examination is primarily concerned with attitudinal differences among Anglos and African Americans, Hispanics were excluded from the analyses presented here.

\section{DEPENDENT VARIABLES}

To capture post racial attitudes, we rely on three measures. First, we examine the extent to which Americans believe discrimination remains a problem in the U.S. If Americans believe that race is not a defining cleavage in American society, they may be less likely to expect that racial discrimination occurs with great frequency. To examine attitudes about discrimination, we rely on a scale based on responses to four questions asking respondents how often they thought blacks were discriminated against in employment, housing, education, and while shopping. The responses to these questions are summed to create a post-racial responses scale for all four questions. ${ }^{4}$

3 The "Racial Attitudes in America" survey was collected from September 5-October 6, 2007. The sample was drawn using random digit dialing (to ensure the oversample of African Americans and Hispanics, the survey disproportionately drew from area codes with higher densities of racial and ethnic minorities). The margin of error for Anglos is $+/-3.5$, and $+/-4$ points for African Americans.

4 See Appendix I for a complete discussion of all the measures and coding used. 
Our second measure of post-racial attitudes is based on a question asking respondents whether they thought then Senator Obama's race would help him, hurt him or make no difference to voters in the 2008 election. We expect that voters who hold post-racial views will believe that Obama's race would make no difference in the election. As such we created a dichotomous variable based on this question ( $1=$ Race will not make a difference, $0=$ Other). This categorization is based on the sociopsychological studies that argue that Whites believe racial distinctions are no longer relevant and instead values are the basis for advancement and discrimination in this country (Kinder and Sears 1981, 1996).

Finally, we expect that Americans holding post-racial attitudes will be less likely to perceive race based differences among African Americans and Anglos. To capture these attitudes, we rely on a question asking respondents whether they thought that the values of black and white people have become more similar or more different in the past 10 years. We expect that those Americans possessing post-racial attitudes will believe the values of these two groups are more similar. Sniderman and Hagan (1985) argue that whites' believe that racial inequalities are no longer the issue but instead racial attitudes should be observed in reference to an adherence to values such as individualism. These scholars assert that whites are more interested in values that promote egalitarianism. If Whites believe that middle class Blacks possess these same values then they will agree that middle class Blacks are more similar to them than lower class Blacks who may not espouse or embrace the values of individualism and less government intervention.

\section{INDEPENDENT VARIABLES}

We anticipate that a number of respondents' characteristics, including political orientations, identity, experiences, and resources, may shape their post-racial attitudes. First, we examine the impact of Americans' racial identity on their post-racial attitudes. Throughout our analyses, we anticipate that Anglos will more frequently express post-racial attitudes, compared with African Americans. We base this expectation upon previous research, which indicates that whites tend to less frequently perceive race as a significant challenge in society (compared with blacks). As Kinder and Sanders put it:

Whites tend to think that racial discrimination is no longer a problem; that prejudice has withered away; that the real worry these days is reverse discrimination, penalizing innocent whites for the sins of the distant past. Meanwhile, blacks see racial discrimination as ubiquitous; they think of prejudice as a plague; they say that racial discrimination, not affirmative action, is still the 
rule in American society." (Kinder and Sanders, 1996, 287)

Similarly, we anticipate that whites are more likely to believe discrimination and race-based voting are a thing of the past, compared with their African American peers. To test this hypothesis, we include a binary variable for race $(1=$ white, 0 -black $)$.

We further anticipate that attitudes towards African Americans and social experiences will influence respondents' attitudes about the persistence of racism in the United States. First, we anticipate that negative affect towards African Americans may be related to a belief about the role of race in society. Affect towards blacks has been found in the past to shape racial attitudes (Tarman and Sears 2005) and may exert a differential impact on our post-racial attitudes here. On the one hand, respondents who report higher opinions of African Americans may be more aware and/or sympathetic to the challenges African Americans face with regard to discrimination. Conversely, positive affect towards African Americans may result in fewer perceived disparities in white and black values, and a belief that race won't make a difference for Obama in the 2008 election. Attitudes towards African Americans is measured relying on a question asking respondents about their overall opinion of blacks $(0=$ Very unfavorable, $3=$ Very favorable.

Social integration may also impact respondents' willingness to express post-racial attitudes. Again, these experiences may exert a differential impact on post-racial attitudes. Contact with members of other racial and ethnic groups may increase awareness of discrimination, while simultaneously positively impacting the extent to which respondents believe race is not a factor in political decision-making and whites and blacks share similar values.

Based on previous research, we further expect that political orientations will significantly shape post-racial attitudes among respondents. Political ideology and party attachment are frequently included in examinations of racial attitudes and have been found in the past (e.g.; Sears, Henry and Kosterman 2000) to shape racial attitudes among whites. We attempt to capture political orientations, relying on two measures. The analyses include measures of party attachment ( $1=$ Republican, $2=$ Independent, $3=$ Democrat), and political ideology $(1=$ Very conservative, 2=Conservative, 3=Moderate, 4=Liberal, 5=Very Liberal).

Finally, a number of demographic characteristics often found to influence racial attitudes (e.g.; Hutchings 2009; Tarman and Sears 2005), including age, education ( $1=$ College education, $0=$ No college), income and gender $(1=$ Female, $0=$ Male $)$, are included in the models. Income captures family income ranging from less than $\$ 10,000$ per year through over $\$ 150,000$ per year. 


\section{RESULTS}

First, we examine the presence of post-racial attitudes among Anglos and African Americans. Table 1 shows the distribution of the three dependent variables and the differences among blacks and whites in their support for these attitudes. First, we can see that the respondents' mean measure on the discrimination scale is 2.28 , indicating that, on average, respondents believed blacks were discriminated against 'hardly ever' or 'not too often' in over 2 of the 4 circumstances described (housing, education, employment, shopping). Among our remaining measures of postracialism, we can see that attitudes about whites and blacks' values becoming more similar are the most prevalent, with $64 \%$ of respondents agreeing. In contrast less than $50 \%$ of respondents believed Obama's race would not matter to voters if he were the Democratic nominee in 2008.

Table 1: Group Differences in Post-Racial Attitudes

\begin{tabular}{|c|c|c|c|}
\hline & $\begin{array}{c}\text { Average score of } \\
\text { Discrimination Scale }^{a b}\end{array}$ & $\begin{array}{l}\text { Obama's Race Won't } \\
\text { Make a Difference } \\
\text { (percent agreeing) }^{\text {ab }}\end{array}$ & $\begin{array}{l}\text { White and Black } \\
\text { Values have become } \\
\text { more similar (percent } \\
\text { agreeing) }\end{array}$ \\
\hline \multicolumn{4}{|l|}{ Race } \\
\hline Whites & 2.86 & $84 \%$ & $56 \%$ \\
\hline Blacks & 1.40 & $61 \%$ & $36 \%$ \\
\hline \multicolumn{4}{|c|}{ Social Integration } \\
\hline Diversity & 2.34 & $76 \%$ & $48 \%$ \\
\hline No Diversity & 1.91 & $63 \%$ & $43 \%$ \\
\hline \multicolumn{4}{|c|}{$\begin{array}{l}\text { a Differences among blacks and whites are statistically significant }(\mathrm{p}<.01) \text {. } \\
\text { b Differences among respondents with racially diverse friends and those without are } \\
\text { statistically significant }(\mathrm{p}<.01)\end{array}$} \\
\hline
\end{tabular}

Next, we examine racial differences, finding a notable divide among blacks and whites in their expression of post-racial attitudes. On a scale of 0-4 (4=Most post racial response), we see whites' average score is more than twice that of black respondents, demonstrating the significant difference among members of these groups in the extent to which blacks face continual discrimination in their daily lives. Turning to our next measure of post-racialism- a question asking respondents whether they believe Obama's race would make a difference in the 2008 election, we can see that over $50 \%$ of white respondents believed Obama's race would be of little consequence in the election, compared with approximately $36 \%$ of blacks. Finally, the data indicates a significant 
divide among whites and blacks on our final measure of post-racialismwhether white and black values have become more similar over the last 10 years. $70 \%$ of whites answered in the affirmative for this question, compared to $55 \%$ of blacks. These descriptive statistics further demonstrate the previous arguments that racial attitudes among blacks and whites differ. Furthermore, these results also show whites are asserting more post racial attitudes than blacks.

While these descriptive statistics give us some indicator of the distribution of post-racial attitudes among Whites and Blacks, to examine them controlling for other variables known to influence racial attitudes, we turn now to our multivariate analyses.

\section{Multivariate Models}

We ran three models predicting our measures of post-racial attitudes. Models I and III (examining beliefs about the persistence of discrimination, and about whites' and blacks' values becoming more similar, respectively) rely on ordered logistic regression, while Model II is a logistic regression predicting the likelihood that respondents believe Obama's race will not make a difference to voters during the 2008 election. Across the models, two sets of results are reported. The first column in each model reports the logistic coefficients with the standard errors in parenthesis and the second set of results reports the average change across the dependent variable, given a fixed change in the independent variable from its minimum to its maximum value, holding all other variables constant at their means (Long and Freese 2006).

The results reported throughout models I-III reveal that, controlling for the other variables in the model, Americans' racial identity consistently influences the extent to which they hold post-racial attitudes. Specifically, being white (rather than black) significantly and positively increased respondents' likelihood of believing discrimination was rare, that race would not make a difference in the 2008 presidential election, and that the values of whites and blacks have become more similar. These results indicate a clear division among blacks and whites in the extent to which they believe race to be a defining cleavage in American society, particularly in the extent to which they believe race to be a significant challenge blacks need overcome in seeking political office, education, housing, and employment. Whites further appear more likely to believe that black-white differences in values have declined in recent years. Thus, Whites believe William Wilson's (1978) assertions that class not race is the most significant division within America. If indeed class, not race is the defining cleavage in America, there must still be consideration of the fact that class issues are often tied to racial issues. Blacks today remain at a substantial disadvantage by most standard in- 
Table 2: Multivariate Models Examining Post-Racial Attitudes

\begin{tabular}{|c|c|c|c|c|c|c|}
\hline & \multicolumn{2}{|c|}{$\begin{array}{l}\text { Model I: Ordered Logistic } \\
\text { Regression: Discrimination is } \\
\text { Rare }\end{array}$} & \multicolumn{2}{|c|}{$\begin{array}{l}\text { Model II: Logistic Regression: } \\
\text { Obama's Race Won't Make a } \\
\text { Difference }\end{array}$} & \multicolumn{2}{|c|}{$\begin{array}{l}\text { Model III: Ordered Logistic } \\
\text { Regression: White and Black } \\
\text { Values have become more } \\
\text { similar }\end{array}$} \\
\hline & Coefficients (S.E.) & Min-Max & Coefficients (S.E.) & Min-Max & Coefficients (S.E.) & Min-Max \\
\hline White & $1.73(.110)^{* *}$ & .162 & $.786(.124)^{* *}$ & .191 & $1.16(.136)^{* *}$ & .158 \\
\hline Age & $-.002(.002)$ & .019 & $.012(.003)^{* *}$ & .251 & $.001(.003)$ & .014 \\
\hline Education & $-.064(.097)$ & .006 & $-.343(.114)^{* *}$ & -.084 & $.068(.127)$ & .008 \\
\hline Income & $.041(.020)$ & .032 & $.032(.024)$ & .064 & $.014(.026)$ & .014 \\
\hline Party Attachment & $-.028(.065)^{* *}$ & .055 & $-.046(.077)$ & -.023 & $-.012(.087)$ & .003 \\
\hline Ideology & $-.143(.046)^{* *}$ & .056 & $-.087(.055)$ & -.086 & $.100(.058)$ & .052 \\
\hline Female & $-.143(.090)$ & .014 & $.091(.104)$ & .022 & $.060(.115)$ & .008 \\
\hline Social Integration & $.375(.132)^{* *}$ & .037 & $.382(.161)^{*}$ & .093 & $.465(.160)^{* *}$ & .066 \\
\hline Black Favorability & $-.081(.069)$ & .024 & $.034(.082)$ & .025 & $.327(.087)^{* *}$ & .141 \\
\hline \multicolumn{7}{|l|}{ Constant } \\
\hline$\chi$ & $542.19 * *$ & & $103.84 * *$ & & $136.20 * *$ & \\
\hline $\mathrm{N}$ & 1786 & & 1656 & & 1681 & \\
\hline
\end{tabular}

Note: ${ }^{*} \mathrm{p}<.05,{ }^{*} \mathrm{p}<.01$. All $\mathrm{p}$-values are based on two-tailed tests 
dicators (Sears et al. 2000). Statistics show that compared with Whites, Blacks suffer disproportionately from unemployment, poverty, inferior educational opportunities, and poor health care (Shaw 1993). All of these are associated with class, but how can we separate class from race, when most class issues disproportionately affect one race over another? The situation of Blacks in America is complex, and there are no easy answers. With these consistent differences, it is no surprise that Blacks consistently perceive more discrimination and less equal opportunity than do Whites (Sears et al., 2000). Even when only considering issues of class, racial concerns still arise. What we may be seeing is that it is simply easier to take explicit racial concerns out of the equation, but due to the connectedness of racial and class issues in America, it becomes more and more difficult to escape cleavages based on race, even when only considering class.

In addition to racial and ethnic identity, social integration exerts a consistent and positive impact on all three measures of post-racialism. Contrary to our expectations, those with more diverse groups of friends less often express concern over discrimination. Initially, we reasoned those with diverse friends would perceive more discrimination from the experiences their friends would describe. However, we cannot conclude this as accurate. We found that views of discrimination do not increase because of an increase in a diverse group of friends. Furthermore, the results indicate that respondents who socialize with a more racially diverse group are more likely to believe that race will not make a difference for Obama in the 2008 election, and that the values of whites and blacks in America have become more similar. To further examine the impact of these social experiences on post-racial attitudes, the differences in the dependent variables among respondents with diverse and non-diverse social groups were examined (results reported in Table 3). Difference of means tests reveal significant variation among these groups in two out of the three variables (discrimination and black/white values).

\section{Table 3: Post-Racial Attitudes by Social Group Diversity}

\begin{tabular}{lccc}
\hline & $\begin{array}{c}\text { Average score of } \\
\text { Discrimination Scale }\end{array}$ & $\begin{array}{c}\text { Obama's Race Won't } \\
\text { Make a Difference } \\
\text { (percent agreeing) }\end{array}$ & $\begin{array}{c}\text { White and Black } \\
\text { Values have become } \\
\text { more similar (percent } \\
\text { agreeing) }\end{array}$ \\
\hline Diverse Social Group & 2.34 & $48 \%$ & $71 \%$ \\
Non-Diverse Social Group & 1.91 & $43 \%$ & $59 \%$ \\
\hline
\end{tabular}

${ }^{\mathrm{a}}$ Differences among respondents with racially diverse friends and those without are statistically significant $(\mathrm{p}<.01)$

Differences in groups means calculated using Analysis of variance (ANOVA) tests. All p-values are based on two-tailed tests. 
The results presented in the first three models also indicate that political orientations, namely party attachment and political ideology, impact attitudes about discrimination. Democrats and liberals are less likely to believe that discrimination is not a significant problem in the United States. However, these orientations show no significant impact on our other measures of post-racial attitudes. Several of the control variables also exert a significant impact on post-racial feelings among respondents. Age negatively impacts attitudes about the role of Obama's race in the 2008 election, and favorability towards blacks increases the likelihood that respondents believe that black and white values have become more similar. Finally, education negatively and significantly impacts the likelihood that respondents' believed Obama's race would make a difference in the 2008 election.

\section{Conclusion}

In 2008 it was realized that race relations in this country had improved, but had not moved toward the racial progression that was expected due to the candidacy and election of an African American for the office of President. The hope for this country was that it had moved on to become the racial melting pot in which everyone was seen as being equal and everyone could be afforded the same opportunity if they worked as hard as their racial counterpart.

However, what has been revealed in the research since Obama became president and even during his candidacy is that maybe our racial melting pot is not hot enough. Research reveals that as we move forward in this country and make strides toward racial solidarity, the old adages about race still linger in the hearts and minds of Americans across the country, both white and black.

Currently, there still continues to be marked differences between the opinions of Blacks and Whites. According to Hutchings and Valentino (2004) differences in opinion between Blacks and White are not small. In fact, differences of over $20 \%$ exist on policies, including nonracial ones (general government spending on social services, education, and assistance for the poor). Surveys show that Black Americans disagree with white Americans about whether the economic situation has improved for Blacks, whether there are more opportunities now, whether competition for jobs is fairly handled, and whether racism in this country has decreased (Shaw 1993). More recently we have observed a division in political attitudes among whites and Blacks in reference to the involvement of the government in the flooding of New Orleans during Hurricane Katrina and the views that then Senator Barack Obama's race would not be a factor in his candidacy for president. Similarly, we find that those who have a more diverse group of friends and those whose 
social interactions are multicultural are less likely to exhibit racist attitudes toward his or her white or black counterparts. Finally, more whites think that they have more values in common with blacks than blacks believe they have in common with whites. However, values is a broad category so we are unable to draw specific conclusions from this comment other than to state that whites feel they share more similarities with Blacks than in the past.

Current events have demonstrated that racial prejudice and discrimination are not over. And, as the country continues on its path toward the equalization of all races in this country, it cannot afford to continue to think that the traditional ways of thinking about race will get them to the end of the road because ultimately, it will continue to lead to a dead end.

\section{BIBLIOGRAPHY}

Bobo, Lawrence, James R. Kluegel, and Ryan A. Smith. 1997. "Laissezfaire Racism : The Crystallization of a Kinder, Gentler, Antiblack Ideology." In Racial Attitudes in the 1990's: Continuity and Change, edited by Steven A. Tuch and Jack K. Martin. Westport Conn:Praeger.

Bobo, Lawrence. 2000. "Race Beliefs about Affirmative Action." In Racialized Politics: the Debate about Racism in America, edited by David O. Sears, Jim Sidanius, and Lawrence Bobo. Chicago, IL: University of Chicago Press.

Cho, Sumi. 2009. "Post-racialism". Iowa Law Review 94(5):15891951.

Devine, Patricia G. 1989. Stereotypes and Prejudice: Their Automatic and Controlled Components. Journal of Personality and Social Psychology, 56, 5-18.

Dovidio, John F. and Samuel L. Gaertner. 1986. The Aversive Form of Racism. In J.F. Dovidio and S. L. Gaertner (Eds.), Prejudice, Discrimination, and Racism.(pp. 61-89). Orlando, FL: Academic Press.

Edge, Thomas. 2010. "Southern Strategy 2.0: Conservatives, White Voters, and the Election of Barack Obama." Journal of Black Studies. 40: 426-444.

Fazio, Russell H., Joni R Jackson, Bridget C Dunton., Carol J. Williams. 1995. "Variability in automatic activation as an unobtrusive measure of racial attitudes: a bona fide pipeline?" Journal of Personality and Social Psychology. 69: 1013-1027. 
Gallagher, Charles. 2003. "Miscounting Race: Explaining Whites' Misperceptions of Racial Group Size". Sociological Perspectives 46(3): 381-396.

Harris-Lacewell Melissa. 2003. "The Heart of the Politics of Race: Centering Black People in the Study of Racial Attitudes". Journal of Black Studies 34(2): 222-249.

Hutchings, Vincent and Nicholas Valentino. 2004. "The Centrality of Race in American Politics". Annual Review of Political Science 7: 383-408.

Hutchings, Vincent. 2009. "Change or More of the Same? Evaluating Racial Attitudes in the Obama Era". Public Opinion Quarterly 73 (5): 917-942.

Kinder, Donald R., and Lynn M. Sanders. 1996. Divided by Color: Racial Politics and Democratic Ideals. Chicago IL: University of Chicago Press.

Kinder, Donald. and Sears, David. 1981. "Prejudice and Politics: Symbolic Racism Versus Racial Threats to the Good Life." Journal of Personality and Social Psychology, 40, 414-431.

Kinder, Donald R., and Tali Mendelberg. 2000. "Individualism Reconsidered: Principles and Prejudice in Contemporary American Opinion." In Racialized Politics: the Debate about Racism in America, edited by David O. Sears, Jim Sidanius, and Lawrence Bobo. Chicago, IL: University of Chicago Press.

Long, Jay Scott, and Jeremy Freese. 2006. Regression Models for Categorical Dependent Variables Using Stata. College Station, Texas: Stata Press.

Metzler, Christopher J. 2010. "Barack Obama's Faustian Bargain and the Fight for America's Racial Soul." Journal of Black Studies 40: 395-410.

Mitchell, Greg. "Racial Incidents and Threats Against Obama Soars: Here is a Chronicle," The Huffington Post, 15 November 2008.

Pettigrew, Thomas F. and Roel W. Meertens. 1995. "Subtle and Blatant Prejudice in Western Europe" European Journal of Social Psychology 25: 5 7-75.

Piston, Spencer. 2010 "How Explicit Racial Prejudice Hurt Obama in the 2008 Election" Political Behavior 32:4.

Sears, David O, P.J. henry, and Rick Kosterman. 2000. Egalitarian Values and Contemporary Racial Politics." In Racialized Politics: the Debate about Racism in America, edited by David O. Sears, Jim 
Sidanius, and Lawrence Bobo. Chicago, IL: University of Chicago Press.

Sears, David O., John J. Hetts, Jim Sidanius and Lawrence Bobo. 2000. "Race in American Politics." In Racialized Politics: the Debate about Racism in America, edited by David O. Sears, Jim Sidanius, and Lawrence Bobo. Chicago, IL: University of Chicago Press.

Sidanius, Jim and Felicia Pratto., 1999. Social dominance: An Intergroup Theory of Social Hierarchy and Oppression. New York: Cambridge University Press.

Sniderman, Paul M., and Michael G. Hagen. 1985. Race and Inequality: A Study in American Values. Chatham, N.J.: Chatham House.

Sniderman, Paul, and Thomas Piazza. 1993. The Scar of Race. Cambridge: Harvard University Press

Sniderman, Paul, and Edward G. Carmines. 1997. Reaching Beyond Race. Cambridge: Harvard University Press.

Sniderman, Paul, Gretchen Crosby, and William Howell. 2000. "Politics of Race" In Racialized Politics: the Debate about Racism in America, edited by David O. Sears, Jim Sidanius, and Lawrence Bobo. Chicago, IL: University of Chicago Press.

Steele, Shelby. 2008. “Obama's Post-Racial Promise: Barack Obama Seduced Whites with a Vision of their Racial Innocence Precisely to Coerce them Into Acting Out of a Racial Motivation." Los Angeles Times (November 5).

Tajfel, H., \& Turner, J. C. 1986. "The Social Identity Theory of Intergroup Behaviour." In S. Worchel \& W. G. Austin (Eds.), Psychology of Intergroup Relations (pp. 7 - 24). Chicago, IL: Nelson-Hall.

Tarman, Christopher, and David O. Sears.2005 "The Conceptualization and Measurement of Symbolic Racism."Journal of Politics. 67:3:731-761.

Teasley, Martell, and David Ikard. 2010. "Barack Obama and the Politics of Race: The Myth of Postracism in America." Journal of Black Studies 40:3:411-425.

Thernstrom, Abigail. 2008. "The Great Black Hope? The Reality of President Elect Obama.” National Review Online.

Wilson, Williams. 1978. The Declining Significance of Race” Blacks and Changing American Institutions. Chicago, Il. University of Chicago Press. 


\section{Appendix 1: Variables \& Measures}

\section{Dependent Variables:}

- Discrimination Scale: "How often do you think blacks are discriminated against when they[ Apply for a job/Try to rent an apartment or find a house to buy/Apply to a college or university/Eat at restaurants and shop in retail stores] - almost always, frequently, not too often, or hardly ever?" ( $1=$ Hardly ever or Not too of ten, $0=$ frequently or=Almost always $)$ *Responses summed to create a scale in which 4 indicates a post-racial response to all 4 questions.

- Obama's Race Won't Make a Difference: If Barack is the Democratic Party nominee for president, do you think his being African-American will help him, hurt him, or won't it make a difference to voters? ( $1=$ Won't make a difference, $0=$ Race will help or hurt him).

- White and Black Values (past 10 years): "Now thinking about people's VALUES. By values I mean things that people view as important, or their general way of thinking. First, in the last ten years do you think the values held by black people and the values held by white people have become more similar or more different?" ( $1=$ More similar, $0=$ No change, $-1=$ More different).

\section{Independent Variables:}

- White: (1=White, $0=$ Black)

- Age: "What is your age" (years)

- Education: "What is the last grade or class that you completed in school?" ( $1=$ college graduate, $0=$ non-college graduate)

- Income: "Last year, that is in 2006, what was your total family income from all sources, before taxes? Just stop me when I get to the right category." ( $1=$ Less than $\$ 10,000,2=10$ to under $\$ 20,000,3=20$ to under $\$ 30,000,4=30$ to under $\$ 40,000,5=40$ to under $\$ 50,000,6=50$ to under $\$ 75,000,7=75$ to under $\$ 100,000,8=100$ to under $\$ 150,000,9$ $=\$ 150,000$ or more."

- Party Attachment: "In politics TODAY, do you consider yourself a Republican, Democrat, or Independent?" (1=Republican, 2=Independent, $3=$ Democrat).

- Ideology: "In general, would you describe your political views as ( $1=$ Very conservative, $2=$ Conservative, $3=$ Moderate, $4=$ Liberal, $5=$ Very liberal).

- Female: (1=Female, $0=$ Male $)$

- Social Integration: "Do you yourself know any person [of another race] whom you consider a friend? " $(0=$ no friends of a different race, $1=$ friend of a different race)

- Black Favorability: "Is your overall opinion of Blacks very favorable, mostly favorable, mostly unfavorable, or very unfavorable?" ( $3=$ very favorable, $2=$ mostly favorable, $1=$ mostly unfavorable, $0=$ very unfavorable). 